\title{
Drug-induced Apoptosis in Hepatoma Cells Is Mediated by the CD95 (APO-1/Fas) Receptor/Ligand System and Involves Activation of Wild-type p53
}

\author{
Martina Müller, ${ }^{\star}$ Susanne Strand, ${ }^{*}$ Hubert Hug, ${ }^{\ddagger}$ Eva-Maria Heinemann, ${ }^{*}$ Henning Walczak, ${ }^{\S}$ Walter J. Hofmann, \\ Wolfgang Stremmel, ${ }^{\star}$ Peter H. Krammer, ${ }^{\S}$ and Peter R. Galle* \\ *University Hospital, Department of Internal Medicine IV, Hepatology and Gastroenterology, Bergheimerstr. 58, 69115 Heidelberg, \\ Germany; ${ }^{\ddagger}$ Center of Molecular Biology, 69120 Heidelberg, Germany; ${ }^{\S}$ German Cancer Research Center, Tumor Immunology Program, \\ 69120 Heidelberg, Germany; and ${ }^{\|}$Institute of Pathology, 69120 Heidelberg, Germany
}

\begin{abstract}
Chemotherapeutic drugs are cytotoxic by induction of apoptosis in drug-sensitive cells. We investigated the mechanism of bleomycin-induced cytotoxicity in hepatoma cells. At concentrations present in the sera of patients during therapy, bleomycin induced transient accumulation of nuclear wild-type (wt) p53 and upregulated expression of cell surface CD95 (APO-1/Fas) receptor in hepatoma cells carrying wt p53 (HepG2). Bleomycin did not increase CD95 in hepatoma cells with mutated p53 (Huh7) or in hepatoma cells which were $\mathrm{p}^{-1-}$ (Hep3B). In addition, sensitivity towards CD95-mediated apoptosis was also increased in wt p53 positive HepG2 cells. Microinjection of wt p53 cDNA into HepG2 cells had the same effect. In contrast, bleomycin did not enhance susceptibility towards CD95-mediated apoptosis in Huh7 and in Hep3B cells. Furthermore, bleomycin treatment of HepG2 cells increased CD95 ligand (CD95L) mRNA expression. Most notably, bleomycin-induced apoptosis in HepG2 cells was almost completely inhibited by antibodies which interfere with CD95 receptor/ligand interaction. These data suggest that apoptosis induced by bleomycin is mediated, at least in part, by p53-dependent stimulation of the CD95 receptor/ligand system. The same applies to other anti-cancer drugs such as cisplatin and methotrexate. These data may have major consequences for drug treatment of cancer and the explanation of drug sensitivity and resistance. (J. Clin. Invest. 1997. 99:403-413.) Key words: apoptosis $\cdot \mathrm{CD} 95 \cdot \mathrm{p} 53 \cdot$ cancer therapy $\bullet$ drug sensitivity

\section{Introduction}

Chemotherapeutic drugs cause DNA damage and kill cancer cells mainly by apoptosis $(1,2)$. The mechanisms of druginduced apoptosis, however, are poorly understood. Recent studies suggest that p53 may be required for apoptosis in cells treated with chemotherapeutic drugs or radiation $(1,3)$. The p53 tumor suppressor gene is an essential mediator of the cel-

Address correspondence to Peter R. Galle, M.D., Department of Internal Medicine IV, University Hospital, Bergheimerstrasse 58, 69115 Heidelberg, Germany. Phone: 49-6221-568737; FAX: 49-6221-564922.

Received for publication 5 September 1996 and accepted in revised form 21 November 1996.

J. Clin. Invest.

(C) The American Society for Clinical Investigation, Inc.

0021-9738/97/02/0403/11 \$2.00

Volume 99, Number 3, February 1997, 403-413 lular response to DNA damage in mammalian cells. Both $\mathrm{G}_{1}$ cell cycle arrest (4-6) and apoptosis (7-9) after DNA damage were shown to depend on normal p53 function (10). The p53 protein senses genotoxic stress or DNA damage. This results in nuclear accumulation of p53. Subsequently, p53 activates the transcription of several genes whose products are involved in DNA repair or apoptosis. Some of the genes regulated by $\mathrm{p} 53$ have been identified. These genes include muscle creatinine kinase (11), gadd/45, waf-1/cip-1, bcl2/bax, cyclin G, mdm2, TGF- $\alpha$, IGF-binding protein, and Fas. (4-6, 12-15). The exact mediators of apoptosis after p53 activation are not known. Owen-Schaub et al. (16) have shown that introduction of wt or temperature-sensitive p53 into human tumor cell lines enhances expression of the CD95 (APO-1/Fas) receptor.

CD95 is a type I transmembrane receptor that belongs to the nerve growth factor/tumor necrosis factor receptor superfamily. Triggering of CD95 by the CD95 ligand (CD95L) or by agonistic antibodies results in rapid induction of apoptosis in susceptible cells (17-19). CD95L has recently been cloned and found to be a type II transmembrane protein that belongs to the corresponding TNF family $(20,21)$.

The CD95 receptor/ligand system plays an important role in downregulation of the immune response. In addition, the CD95 and the perforin system mediate $\mathrm{T}$ cell cytotoxicity (22-24). CD95 is constitutively expressed in a wide range of tissues, including the liver (25-27). The liver is highly sensitive to CD95-mediated induction of apoptosis. Thus, mice injected intraperitoneally with anti-CD95 antibody died within several hours from fulminant hepatic failure due to generalized apoptosis of hepatocytes (26). Likewise, human hepatocytes in primary culture undergo apoptosis upon stimulation with agonistic anti-CD95 antibodies (25). Moreover, upregulated CD95 receptor- and/or CD95L mRNA levels were detected in different acute and chronic liver diseases (25).

We have analyzed the mechanisms by which cytotoxic drugs kill hepatoma cells in vitro. We found that these drugs kill these cells by induction of apoptosis. Therefore, we tested whether drug-induced apoptosis involves the CD95 receptor/ ligand system and is dependent on the function of p53. Our data show that antineoplastic drugs induce apoptosis in wt p53 carrying hepatoma cells by upregulation of the CD95 receptor and the CD95L.

\section{Methods}

\section{Cell lines}

The following cell lines were used: $(a)$ HepG2 cells derived from a human hepatoblastoma (28) only expressing small amounts of wildtype p53 (unpublished sequence data from our laboratory); (b) Huh7 cells derived from a hepatocellular carcinoma (29) and shown to ex- 
press p53 with increased half life as a result of a point mutation at codon 220 (30); and (c) Hep3B cells (28) deficient of p53 (31). HepG2 and Huh7 cells were maintained in Dulbecco's modified Eagle medium (DMEM; Flow Laboratories, Meckenheim, Germany) containing $10 \% \mathrm{FCS}, 5 \mathrm{mmol} / \mathrm{liter}$ glutamine, $100 \mu \mathrm{g} / \mathrm{ml}$ penicillin (all from Flow Laboratories).

Hep3B were grown in MEM (Milieu Essentiel Minimum; Laboratoires Eurobio, Raunheim, Germany).

\section{Treatment with anticancer agents}

The different cell lines were treated with bleomycin (Mack, Illertissen, Germany) at a dose range of $60 \mathrm{ng} / \mathrm{ml}$ to $6 \mathrm{mg} / \mathrm{ml}$, or with doxorubicin (Rhône-Poulenc, Köln, Germany) at a dose range of $0.4 \mathrm{ng} / \mathrm{ml}$ to $4 \mu \mathrm{g} / \mathrm{ml}$ for $3 \mathrm{~h}$ up to $72 \mathrm{~h}$. Furthermore, cisplatin at a dose range of $0.1 \mathrm{ng} / \mathrm{ml}$ to $0.1 \mathrm{mg} / \mathrm{ml}$ or methotrexate at a dose range of $0.1 \mathrm{ng} / \mathrm{ml}$ to $1 \mathrm{mg} / \mathrm{ml}$, were applied. The concentrations relevant for therapy are $1.5-3.0 \mu \mathrm{g} / \mathrm{ml}$ for bleomycin (32), $0.4-1.6 \mu \mathrm{g} / \mathrm{ml}$ for cisplatin $(33,34)$, $7-12 \mu \mathrm{g} / \mathrm{ml}$ for methotrexate (35), and $0.001-0.02 \mu \mathrm{g} / \mathrm{ml}$ for doxorubicin (36) in patients' sera.

\section{Treatment with IgG 3 anti-APO-1 and $F(a b)_{2}{ }_{2}$-anti-APO-1}

CD95 receptor stimulation was performed with the monoclonal antibody anti-APO-1 at concentrations of $100 \mathrm{ng} / \mathrm{ml}$ as described (17, 37, 38). CD95 receptor blocking experiments were performed by treatment with $\mathrm{F}(\mathrm{ab})^{\prime}{ }_{2}$-anti-APO-1 fragments as previously described (38).

\section{Statistical analysis}

To examine whether synergy $(39,40)$ between APO-1 stimulation and concurrent bleomycin treatment is observed, a balanced two-way ANOVA (model with fixed effects) was performed. Statistical analysis was carried out with the SAS software system (SAS Institute Inc., Cary, NC).

\section{Immunohistochemistry}

HepG2 cells grown on cover slips were fixed for $2 \mathrm{~min}$ in a 1:1 (vol/ vol) mixture of acetone and methanol and air dried. Immunohistochemistry of p53 was performed as described (41), using Do1 (Dianova, Hamburg, Germany) as first antibody.

\section{Immunoblot (Western blot)}

Cultured cells were homogenized in sample buffer $(50 \mathrm{mM}$ Tris-CL, pH 6.8, 2\% SDS, $100 \mathrm{mM}$ dithiothreitol). Protein concentration was measured using the Bio-Rad protein assay (Bio-Rad Laboratories, Munich, Germany). Briefly, an aliquot of each sample equivalent to $10 \mu \mathrm{g}$ protein was boiled in $20 \mu \mathrm{l}$ sample buffer, separated on a $12 \%$ SDS-polyacrylamide gel (PAGE), and electrophoretically transferred to nitrocellulose filters using the Bio-Rad electrotransfer system (Bio-Rad Laboratories, Munich, Germany). P53 was detected with the mouse monoclonal antibody PAb 1801 (Dianova, Hamburg, Germany) or the polyclonal rabbit antiserum HZp53R as first antibody as described (42).

\section{Metabolic labeling with ${ }^{35}$ S/methionine, immunoprecipitation, and autoradiography}

HepG2 and Huh7 cells were plated in six-well dishes $\left(2 \times 10^{5} /\right.$ well $)$ at $60 \%$ confluence. Cells were treated with bleomycin or doxorubicin as described above for $3 \mathrm{~h}$. HepG2 and Huh7 cells were then metabolically labeled for $3 \mathrm{~h}$ in $2 \mathrm{ml}$ of $10 \%$ dialyzed FCS/methionine-free medium with $20 \mu \mathrm{Ci} / \mathrm{ml}\left[{ }^{35} \mathrm{~S}\right]$ methionine. Cells were collected with a rubber policeman and centrifuged for $5 \mathrm{~min}$ at $13,000 \mathrm{~g}$. The cells were lysed in lysis buffer (50 mM Tris, $\mathrm{pH} 8.0,150 \mathrm{mM} \mathrm{NaCl}, 5 \mathrm{mM}$ EDTA, 1\% NP-40, 1 mM PMSF).

Monoclonal antibodies PAb 1801 or PAb 421 (Dianova, Hamburg, Germany) were adsorbed to $20 \mu \mathrm{l}$ of preswollen protein A-Sepharose (Sigma, Munich, Germany) in phosphate-buffered saline (PBS) for $2 \mathrm{~h}$ at room temperature. After washing three times with lysis buffer supernatants of the cells were added and incubated $2 \mathrm{~h}$ at room temperature.
The immunoprecipitates were boiled in sample buffer and separated by $10 \%$ SDS-PAGE. The gel was then dried and subjected to autoradiography.

\section{$\left[{ }^{3} \mathrm{H}\right]$ Thymidine incorporation}

Cell proliferation was determined in $35-\mathrm{mm}$ culture plates. $1 \mu \mathrm{Ci} / \mathrm{ml}$ $\left[{ }^{3} \mathrm{H}\right]$ thymidine (Amersham Buchler, Braunschweig, Germany) was added to each culture well for $3 \mathrm{~h}$ before harvesting the cells. Subsequently, the tissue culture plates were placed on ice and the liver cells washed twice with ice-cold PBS and harvested with $1 \%$ Triton X-100/PBS.

Incorporated $\left[{ }^{3} \mathrm{H}\right]$ thymidine was measured in a liquid scintillation counter (Beckman, Munich, Germany). Growth inhibition by bleomycin or doxorubicin was calculated as the percentage reduction in $\left[{ }^{3} \mathrm{H}\right]$ thymidine uptake compared with untreated controls. Results are shown as the mean of six independent culture plates \pm SD.

\section{Detection of apoptosis}

$F A C S^{\circledR}$ analysis. Apoptosis was assessed by fluorescence-activated cell sorting $\left(\mathrm{FACS}^{\circledR}\right)$ analysis carried out in a FACScan ${ }^{\circledR}$ flow cytometer (Becton Dickinson, Heidelberg, Germany) using the LYSIS II software system.

Hepatocytes, floating in the culture medium were collected by centrifugation at $200 \mathrm{~g}$. Adherent hepatocytes were harvested by incubation with $1 \%$ trypsin for $1 \mathrm{~min}$. The cells were washed with PBS, fixed in $70 \%$ ethanol and stained with propidium iodide $(50 \mu \mathrm{g} / \mathrm{ml}$ PBS). DNA fluorescence was measured in a FACScan ${ }^{\circledR}$ according to the method of Nicoletti et al. (43).

DNA fragmentation. Internucleosomal DNA fragmentation was assessed by the method of Sellins and Cohen as described (44) after harvesting adherent and floating cells from a $70 \mathrm{~cm}^{2}$ subconfluent culture dish.

DAPI and TUNEL staining. Cells were grown on plastic cover slips. DAPI (4',6-diamidino-2-phenylindole; Sigma, Munich, Germany) staining of cellular DNA, was performed as described (25). The cover slips were viewed under the fluorescence microscope (Zeiss, Axiophot, Göttingen, Germany) at $420 \mathrm{~nm}$.

TUNEL staining (45) was performed as described in the Boehringer kit (Boehringer, Mannheim, Germany).

\section{Microinjection}

For microinjection about 2,000 HepG2 cells were seeded onto CELLocate coverslips (Eppendorf, Hamburg, Germany). The following day about 50 cells (per coverslip) in DMEM supplemented with $10 \%$ FCS, $1 \times$ non-essential amino acids (GIBCO, Eggenstein, Germany) and $10 \mathrm{mM}$ Hepes ( $\mathrm{pH}$ 7.4) were injected with $100 \mathrm{ng} / \mu \mathrm{l} \mathrm{H}_{2} \mathrm{O}$ p53 wild-type DNA or different control DNA constructs with the CMV promoter in $1 \%$ tetramethylrhodamine isothiocyanate-dextran $\left(M_{\mathrm{r}}=\right.$ 4400) using the Microinjector 5242 (Eppendorf, Hamburg, Germany) connected to the automated injection system (Zeiss, Göttingen, Germany). The settings were $70-100 \mathrm{hPa}$ and $0.1 \mathrm{~s}$. After $48 \mathrm{~h}$ of incubation the medium was changed and $100 \mathrm{ng} / \mathrm{ml}$ agonistic IgG3 antiAPO-1 mAb were added and the cells were further incubated for $24 \mathrm{~h}$. Surviving microinjected cells were counted under the fluorescence microscope.

Immunostaining of p53. After microinjection and further incubation for $48 \mathrm{~h} \mathrm{HepG} 2$ cells were fixed in methanol and washed with PBS/0.1\% Triton X-100. p53 was stained with the mouse monoclonal antibody PAb $1801(10 \mathrm{ng} / \mathrm{ml})$ followed by FITC-conjugated goatanti-mouse IgG $(5 \mathrm{ng} / \mathrm{ml})$.

\section{Detection of CD95 (APO-1/Fas)}

CD95 cell surface expression was assessed by FACScan ${ }^{\circledR}$. Anti-APO-1 $(\mathrm{IgG} 3, \kappa)$ was used as purified biotinylated antibody. Quantum Red streptavidin (Sigma, Munich, Germany) was used as secondary reagent for indirect immunofluorescence. All purchased reagents were used according to the manufacturer's instructions. Fluorescence analysis was carried out at $4^{\circ} \mathrm{C}$ in PBS with $0.1 \%$ sodium azide. Hepatoma 
cells were incubated in $200 \mu \mathrm{l}$ staining buffer with biotinylated antiAPO-1. After 15 min incubation, cells were washed twice, incubated for 15 min with Quantum Red streptavidin, washed twice again and assayed. Upon data acquisition a gate was set on intact cells by forward/side scatter analysis and 5,000-10,000 viable cells were analyzed.

\section{Detection of CD95 ligand expression by in situ hybridization}

HepG 2 cells at $60 \%$ confluence were incubated on two-well chamber slides (Lab-Tek ${ }^{\circledR}$, Nunc Inc., Naperville, IL) with $6 \mathrm{mg} / \mathrm{ml}$ bleomycin for $24 \mathrm{~h}$. After washing with PBS the cells were fixed for $20 \mathrm{~min}$ in $4 \%$ paraformaldehyde, dehydrated in ethanol and air dried.

For in situ hybridization the cells were pretreated for $20 \mathrm{~min}$ at $37^{\circ} \mathrm{C}$ with proteinase $\mathrm{K}(1 \mu \mathrm{g} / \mathrm{ml}$ in $2 \times \mathrm{SSC} ; 0.1 \%$ SDS $)$. The reaction was stopped by $0.1 \mathrm{M}$ glycine, the cells were fixed with $4 \%$ paraformaldehyde and washed with $2 \times$ SSC. After treatment for $10 \mathrm{~min}$ in
$0.25 \%$ acetic anhydride in $0.1 \mathrm{M}$ triethanolamine, $\mathrm{pH} 8.0$ the cells were dehydrated through an ascending series of ethanol and air dried.

Digoxygenin labeled anti-sense RNA corresponding to the sequence coding for amino acids 100 to 246 of the human CD95-ligand was generated using in vitro transcription with $\mathrm{T} 7$ polymerase (Boehringer, Mannheim, Germany). The length was reduced to approximately 250 nucleotide fragments by limited alkaline hydrolysis (46). The hybridization mixture contained $100 \mathrm{pg} / \mu$ l digoxygenin-labeled RNA, $50 \%$ deionized formamide, $10 \%$ dextran sulfate, $2 \times$ SSC, $1 \times$ Denhardt's mixture $(0.02 \%$ wt $/ \mathrm{vol}), 0.1 \%$ SDS, $500 \mu \mathrm{g} / \mathrm{ml}$ yeast tRNA, $100 \mu \mathrm{g} / \mathrm{ml}$ hering sperm DNA. This mixture was spread over the pretreated, dried cells and covered with parafilm. The slides were incubated overnight at $37^{\circ} \mathrm{C}$ in a moist chamber containing $50 \%$ formamide. Thereafter, the slides were washed with $2 \times$ SSC (30 min), digested with $5 \mu \mathrm{g}$ RNase A (20 min) and again washed with $0.5 \times \mathrm{SSC}$ $(20 \mathrm{~min})$ at $37^{\circ} \mathrm{C}$.

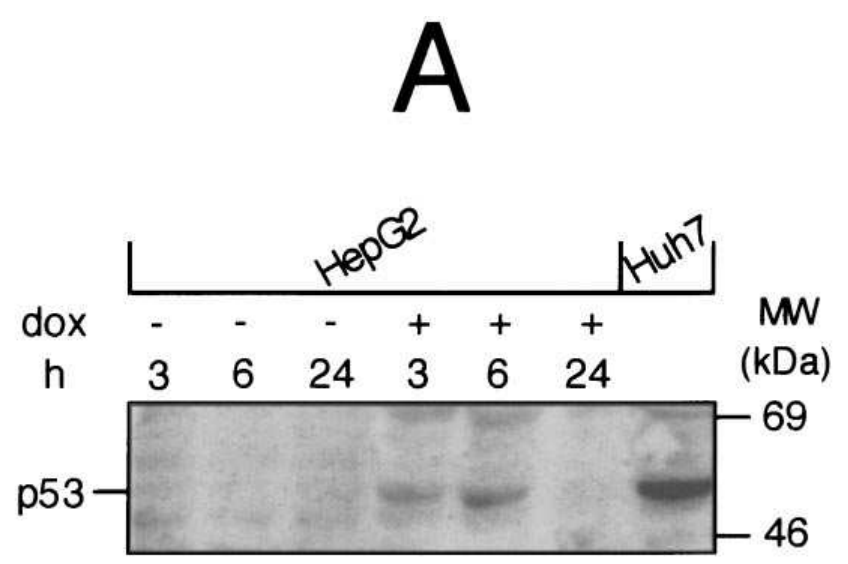

B
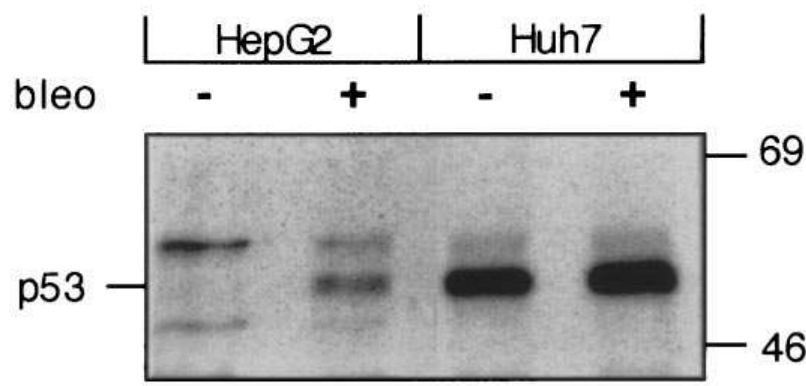
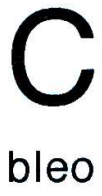

$3 \mathrm{~h}$
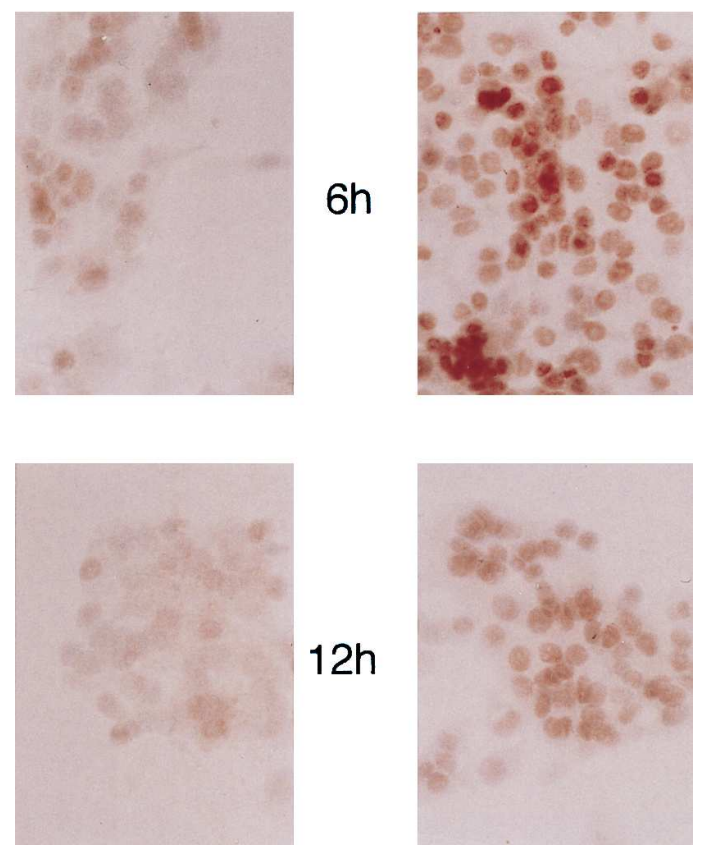

Figure 1. P53 induction in HepG2 cells after treatment with DNA-damaging agents. $(A)$ Western blot of HepG2 cells treated with doxorubicin, $4 \mathrm{ng} / \mathrm{ml}(\mathrm{dox}+)$, demonstrating a transient increase in p53 levels 3-6 h after the onset of treatment. Huh7 cells with mutant p53 served as positive control. (B) Autoradiography after endogenous labeling with $\left[{ }^{35} \mathrm{~S}\right]$ methionine and immunoprecipitation of p53 3-6 h after the onset of bleomycin treatment, $6 \mathrm{mg} / \mathrm{ml}$ (bleo + ), demonstrates synthesis of p53. (C) Immunohistochemistry of HepG2 cells after treatment with bleomycin, 6 $\mathrm{mg} / \mathrm{ml}$ (bleo + , right panel), reveals nuclear accumulation of p53. (Left panel) Untreated controls. 
Digoxygenin-labeled RNA was detected immunologically by a polyclonal anti-digoxygenin sheep antibody conjugated with alkaline phosphatase (Boehringer), visualized using NBT and BCIP as substrate at room temperature overnight in the dark. Slides were mounted with Elvanol and viewed under a microscope (Zeiss, Axiophot, Göttingen, Germany).

\section{Detection of CD95 ligand $m R N A$ expression by PCR}

Total cellular RNA was prepared from $1 \times 10^{6}$ HepG2, Hep3B and Huh7 cells treated with $0.6 \mathrm{mg} / \mathrm{ml}$ and $6 \mathrm{mg} / \mathrm{ml}$ bleomycin for $24 \mathrm{~h}$, using the Rneasy-Kit (Qiagen, Hilden, Germany), following the manufacturer's instructions. The efficiency of the RT and the amount of RNA used in the RT-PCR were verified by detection of the human $\beta$-actin mRNA with RT-PCR. $1 \mu \mathrm{g}$ of total cellular RNA was retrotranscribed after heat denaturation $\left(3 \mathrm{~min}, 60^{\circ} \mathrm{C}\right)$ and annealing with oligo (dT) primers (16-mer, Perkin Elmer, Weiterstadt, Germany) in the presence of $75 \mathrm{U}$ MnLV RT (Perkin Elmer), $67 \mu \mathrm{M}$ $\mathrm{MgCl}_{2}$ and $63 \mu \mathrm{M}$ of each dNTP in $20 \mu \mathrm{l}$ for $45 \mathrm{~min}$ at $42^{\circ} \mathrm{C}$. Reactions were stopped by heat inactivation for $5 \mathrm{~min}$ at $90^{\circ} \mathrm{C}$. Aliquots of $10 \mu \mathrm{l}$ of the cDNA were then amplified in a DNA thermocycler (Stratagene, Heidelberg, Germany) with $2.5 \mathrm{U}$ of Ampli Taq DNApolymerase AS (Perkin Elmer), $10 \mathrm{pM}$ of both upstream and downstream APO-1L Primers, and $2.5 \mu \mathrm{M}$ of both upstream and downstream human $\beta$-actin primers in a volume of $50 \mu \mathrm{l}$. Each PCR cycle consisted of a denaturation step $\left(94^{\circ} \mathrm{C}, 1 \mathrm{~min}\right)$, an annealing step $\left(56^{\circ} \mathrm{C}, 1 \mathrm{~min}\right)$, and an elongation step $\left(72^{\circ} \mathrm{C}, 1 \mathrm{~min}\right)$. The primers used for amplification of the CD95L have been described recently (47). The PCR products were analyzed on a 1.4\% TBE agarose gel.

\section{Cytotoxicity assay}

Crystal violet assay. A $100 \mu \mathrm{l}$ suspension of $7 \times 10^{3}$ cells was added to each well of 96-well plates $24 \mathrm{~h}$ before the assay. Various concentrations of anti-APO-1, bleomycin and $\mathrm{F}(\mathrm{ab})^{\prime}{ }_{2}$-anti-APO- 1 fragments were added to the target cells. After 3-72 h, cells were stained with $0.5 \%$ crystal violet in $20 \%$ methanol. Cell viability was determined by eluting the dye from the stained cells with $0.1 \mathrm{M}$ sodium citrate $/ 0.1 \mathrm{M}$ citric acid and 50\% ethanol, and absorbance was measured at $540 \mathrm{~nm}$ (48).

MTT assay. The MTT assay is a colorimetric assay based on the ability of the viable cells to reduce a soluble yellow tetrazolium salt (MTT) to blue formazan crystals. The cells were plated as described above for the crystal violet assay and appropriate concentrations of the different drugs were added. After 3-72 h $5 \mathrm{mg} / \mathrm{ml}$ MTT dye was added and the plates were incubated for $12 \mathrm{~h}$. Optical density was determined by eluting the dye with isopropanol/formic acid, and absorbance was measured at $540 \mathrm{~nm}$.

Crystal violet and MTT assay were performed in parallel. Results are shown as the mean of six independent wells \pm SD. To rule out that drug treated cells may simply arrest growth, making it difficult to de-


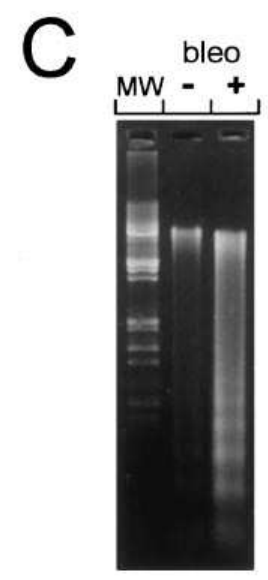

Figure 2. Induction of growth arrest and apoptosis in hepatoma cells by treatment with DNA damaging agents. $(A)$ DNA-synthesis as measured by $\left[{ }^{3} \mathrm{H}\right]$ thymidine incorporation in HepG2 cells bearing wt p53 $(\boldsymbol{\Delta})$ and in Huh7 cells with mutant p53 (ם) treated with bleomycin, $6 \mathrm{mg} / \mathrm{ml}$. Data are shown as the mean \pm SD of six independent culture plates and are expressed as percentage of untreated controls. $(B)$ Kinetics of induction of apoptosis as detected by propidium iodide staining and $\mathrm{FACS}^{\circledR}$ analysis of HepG2 cells treated with bleomycin, $6 \mathrm{mg} / \mathrm{ml}(\boldsymbol{\Delta})$. Untreated controls $(\triangle)$. $(C)$ Internucleosomal DNA fragmentation (DNA-"laddering") after treatment of HepG2 cells with $6 \mathrm{mg} / \mathrm{ml}$ bleomycin (bleo + ). 
termine what percentage of the reduced crystal violet/MTT is due to apoptosis, all cytotoxicity assays were verified by $\mathrm{FACS}^{\circledR}$ analysis using the Nicoletti method (43) to assess specific apoptosis.

\section{Results}

Transient nuclear p53 accumulation after treatment of hepatoma cells with DNA damaging agents. Untreated HepG2 cells only showed basal p53 expression. Treatment of HepG2 cells with bleomycin or doxorubicin resulted in transient accumulation of p53 as detected by Western blotting (Fig. $1 A$ ). An increased p53 signal was detectable $3 \mathrm{~h}$ after the onset of drug treatment. Maximum levels of about 5 to 10 times the control values were reached within 3 to $6 \mathrm{~h}$ after treatment. Elevated p53 levels returned to control values within $24 \mathrm{~h}$ after treatment. (Fig. $1 \mathrm{~A}$ ). Likewise, 3 to $6 \mathrm{~h}$ after the onset of drug treatment of HepG2 cells a transient increase of $\left[{ }^{35} \mathrm{~S}\right]$ methionine-labeled p53 was observed (Fig. $1 B$ ). In contrast to HepG2 cells, Huh7 cells expressing high constitutive levels of mutated p53 (p53-220 cys) (Fig. 1, $A$ and $B$ ) did not show a significant increase in p53 expression after drug treatment (Fig. $1 B$ ). Hep3B cells without endogenous p53 expression did not show a p53 signal by Western blotting before and after bleomycin treatment (data not shown). In HepG2 cells immunohistological analysis revealed increased p53 levels and showed a clear nuclear accumulation of the protein induced by bleomycin treatment (Fig. $1 C$ ).

Induction of growth arrest and apoptosis by DNA damaging agents in human hepatoma cells. $\left[{ }^{3} \mathrm{H}\right]$ Thymidine incorporation in HepG2 cells after treatment with DNA damaging agents showed a significant reduction in DNA synthesis. In contrast, Huh7 cells were remarkably insensitive to doxorubicin- and bleomycin treatment (Fig. $2 A$ ).

We further investigated whether growth arrest after treatment by cytotoxic drugs was due to induction of apoptosis. Propidium iodide staining and FACS ${ }^{\circledR}$ analysis revealed induction of apoptosis in bleomycin-treated HepG2 cells (Fig. 2 B). Apoptosis was also shown by the typical "ladder" pattern of DNA fragmentation (Fig. $2 C$ ).

Upregulation of the CD95 receptor in HepG2 cells and increased responsiveness towards induction of apoptosis by antiAPO-1 antibodies after bleomycin treatment. To study the involvement of the CD95 receptor/ligand system in drug-induced apoptosis we investigated CD95 mRNA and protein expression by semi-quantitative RT-PCR and FACS ${ }^{\circledR}$ analysis.

Bleomycin treatment resulted in enhanced transcriptional activation shown by augmentation of CD95 mRNA expression in HepG2 cells with wt p53. Huh7 cells (mut 220) and Hep3B cells (p53 -/-) did not upregulate CD95 mRNA upon bleomycin treatment (Fig. $3 A$ ).

HepG 2 cells showed a basal expression of the CD95 receptor in 10 to $15 \%$, Huh7 cells in up to $3 \%$ and Hep3B cells in up to $3 \%$ of the cells. HepG2 cells revealed a marked upregulation of the CD95 receptor after drug treatment, up to $80 \%$ receptor expressing cells. This upregulation was only seen in wt p53 expressing HepG2 cells (Fig. $3 B$ ). In contrast, neither Huh7 cells, bearing a point mutation in codon 220 of the p53 gene, nor Hep3B cells, lacking p53, responded to bleomycin treatment with upregulation of the CD95 receptor (Fig. $3 B$ ).

Upregulation of CD95 receptor expression after drug treat-



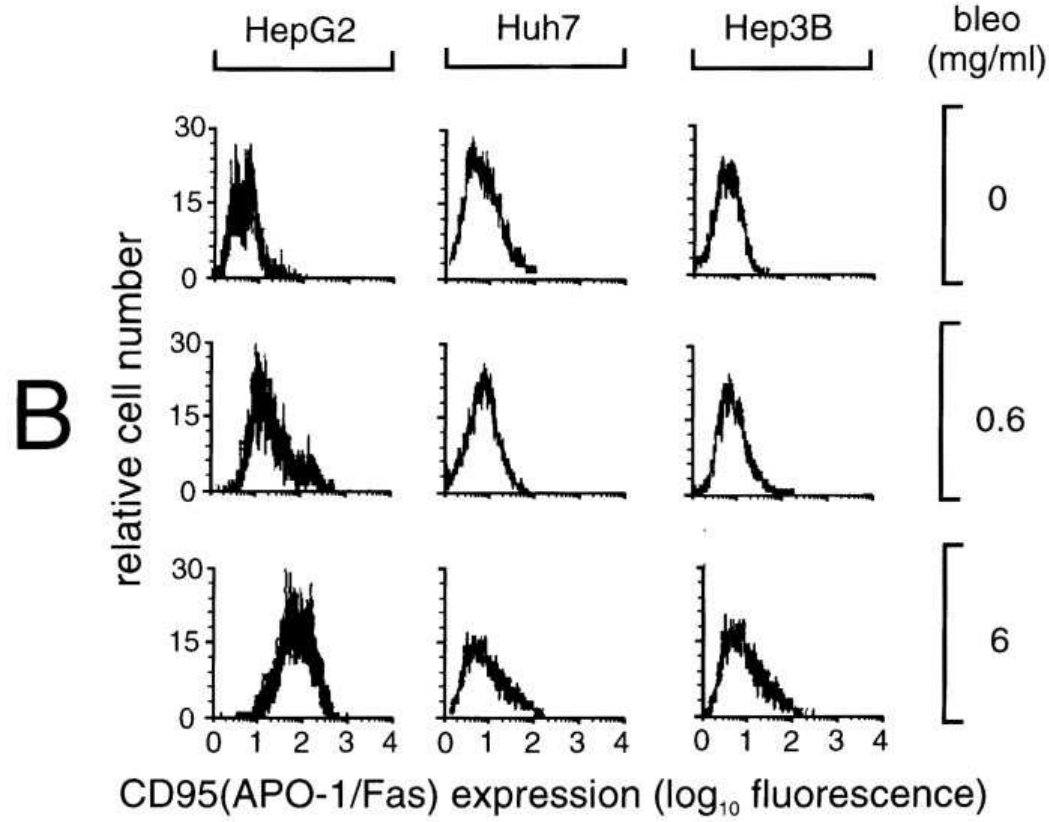

CD95(APO-1/Fas) expression ( $\log _{10}$ fluorescence)
Figure 3. Upregulation of the CD95 receptor after bleomycin treatment. (A) Semi-quantitative RT-PCR analysis of CD95 receptor mRNA expression in HepG2, Hep3B and Huh7 cells after treatment with bleomycin 0.6 and $6 \mathrm{mg} / \mathrm{ml}$. CD 95 mRNA was induced in HepG2 cells (p53 wt) but not in Huh7 cells with mutant p53 and not in Hep3B cells without p53. (B) CD95 receptor expression by FACS ${ }^{\circledR}$ analysis in HepG2 with wt p53 (left column), Huh7 with mutant p53 (middle column) and Hep3B lacking p53 (right column). Cells were left untreated (upper panel) or received treatment with $0.6 \mathrm{mg} / \mathrm{ml}$ bleomycin (middle panel) or $6 \mathrm{mg} / \mathrm{ml}$ bleomycin (lower panel). Only HepG2 cells displayed enhanced CD95 receptor expression up to over $80 \%$ positive cells in response to bleomycin treatment in a dose dependent manner. 

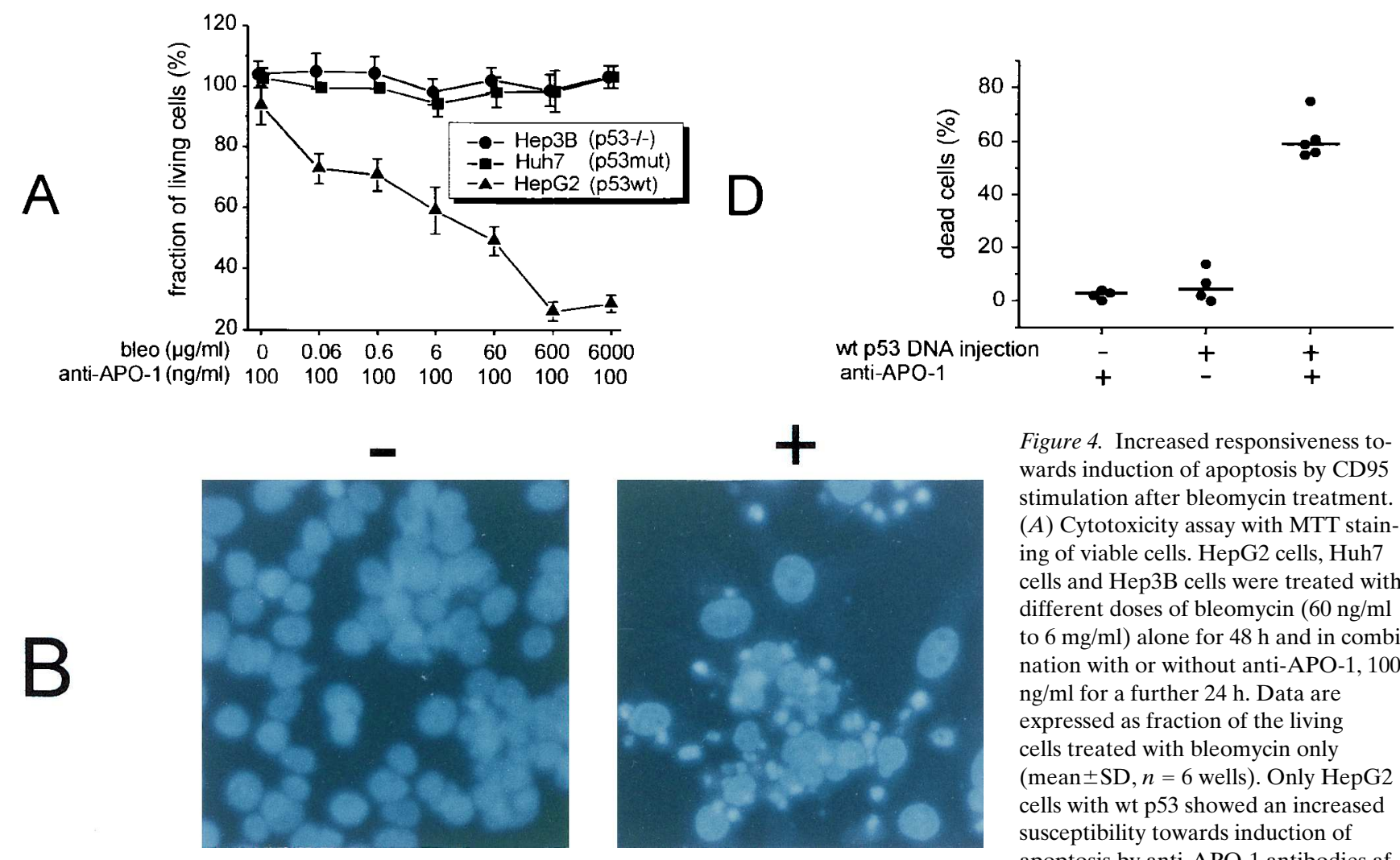

Figure 4. Increased responsiveness towards induction of apoptosis by CD95 stimulation after bleomycin treatment. (A) Cytotoxicity assay with MTT staining of viable cells. HepG2 cells, Huh7 cells and Hep3B cells were treated with different doses of bleomycin $(60 \mathrm{ng} / \mathrm{ml}$ to $6 \mathrm{mg} / \mathrm{ml}$ ) alone for $48 \mathrm{~h}$ and in combination with or without anti-APO-1, 100 $\mathrm{ng} / \mathrm{ml}$ for a further $24 \mathrm{~h}$. Data are expressed as fraction of the living cells treated with bleomycin only (mean $\pm \mathrm{SD}, n=6$ wells). Only HepG 2 cells with wt p53 showed an increased susceptibility towards induction of apoptosis by anti-APO-1 antibodies after bleomycin treatment. A two-way
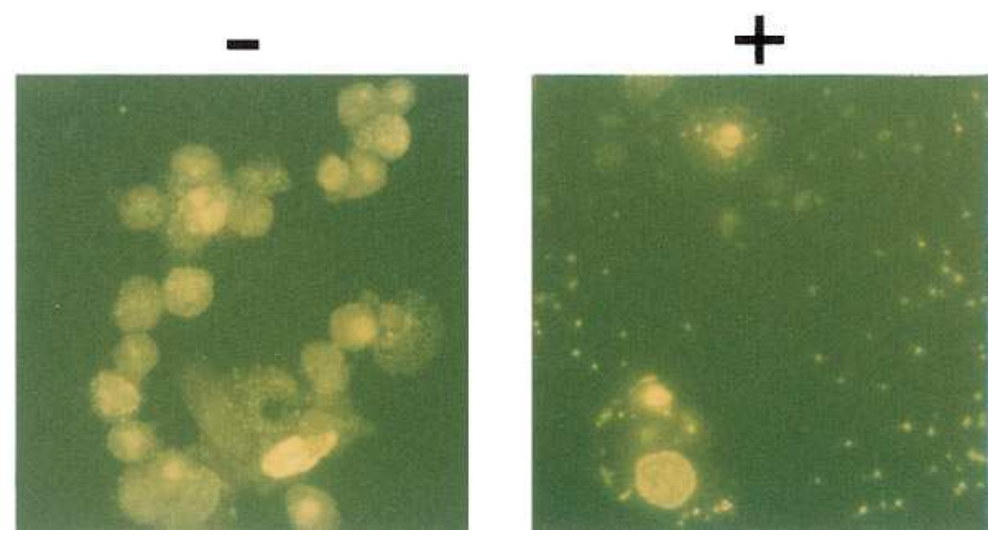
ANOVA with fixed effects revealed a synergistic interaction between antiAPO-1- and bleomycin-induced cell death $(P<0.0001)$. $(B)$ DAPI staining and $(C)$ TUNEL staining of HepG2 cells treated with $6 \mathrm{mg} / \mathrm{ml}$ bleomycin alone $(-)$ for $48 \mathrm{~h}$ or in combination with $100 \mathrm{ng} / \mathrm{ml}$ anti-APO-1 (+) for a further $24 \mathrm{~h}$. Combined treatment led to an increase in nuclear condensation and fragmentation as morphological signs of apoptosis. $(D)$ Increased responsiveness towards induction of apoptosis by CD95 stimulation after microinjection of wt p53 cDNA. HepG2 cells (about 50 cells per experiment) were microinjected with wt p53 cDNA in 4 independent experiments. After $48 \mathrm{~h} 100 \mathrm{ng}$ anti-APO-1 was added for $12 \mathrm{~h}$ and the surviving cells were counted under the microscope. Each dot represents the percentage of dead cells/microinjected cells from an independent well.

ment resulted in increased responsiveness towards CD95 stimulation. Treatment with anti-APO-1 alone led to specific cell death in up to $10 \%$ of the HepG 2 cells, whereas it did not affect viability in Huh7 and Hep3B cells (Fig. $4 A$ ). In HepG2 cells treated with bleomycin for $48 \mathrm{~h}$, CD95 receptor stimulation with anti-APO-1 resulted in induction of apoptosis in up to $75 \%$ of the cells, dependent on the concentration of bleomycin applied (Fig. 4, $A-C$ ). Stimulation of CD95 by anti-APO-1 and concurrent bleomycin treatment did not only show an additive effect but synergized in the induction of apoptosis in p53 wt hepatoma cells. To test for synergy a two-way ANOVA model with fixed effects was performed $(P<0.0001)$.

As a control, the p53 mutant Huh7 cells and the p53 null Hep3B cells were tested. Anti-APO-1 did not produce addi- tional toxicity in comparison with bleomycin treatment alone in Huh7 and in Hep3B cells (Fig. 4 A). Similar as bleomycin treatment microinjection of wt p53 cDNA into HepG2 cells resulted in nuclear accumulation of p53 (not shown) and increased sensitivity towards CD95 mediated apoptosis (Fig. 4D).

Induction of apoptosis by bleomycin is mediated by increased expression of CD95L. To obtain further insight into the mechanism of bleomycin-induced apoptosis, we also analyzed CD95L expression upon drug treatment. Fig. $5 A$ shows by in situ-hybridization that CD95L mRNA is highly elevated upon treatment of HepG2 cells with bleomycin. This was confirmed by PCR analysis. Bleomycin, at concentrations measured in patients' sera during therapy, stimulated CD95L mRNA expression in vitro in HepG2 cells. Hep3B cells (p53-/-) did 



Figure 5. Induction of the CD95L by bleomycin. (A) CD95L mRNA in-situ hybridization of untreated HepG2 cells $(-)$ and after treatment with $6 \mathrm{mg} / \mathrm{ml}$ bleomycin for $24 \mathrm{~h}$ (+). (B) Semi-quantitative PCR analysis of CD95L mRNA expression in HepG2, Hep3B and Huh7 cells upon treatment with bleomycin $0.6 \mathrm{mg} / \mathrm{ml}$ and $6 \mathrm{mg} /$ ml. CD95L mRNA expression was induced in HepG2 cells (p53wt) and in Hep3B cells (p53-/-) but not in Huh7 cells (p53mut). (C) Inhibition of bleomycin-induced apoptosis by $\mathrm{F}(\mathrm{ab}){ }_{2}{ }_{2}$-anti-APO-1. Cytotoxicity assay with crystal violet staining of viable cells. HepG2 cells were treated with $6 \mathrm{mg} / \mathrm{ml}$ bleomycin for $72 \mathrm{~h}$ alone or in combination with CD95 receptor-antagonizing $\mathrm{F}(\mathrm{ab})^{\prime}{ }_{2}$-antiAPO-1 antibody fragments. $\mathrm{F}(\mathrm{ab}){ }^{\prime}{ }_{2}$-anti-APO-1 antibody fragments were able to preserve up to $80 \%$ of the cells from death.

also respond by CD95L upregulation towards bleomycin treatment. In contrast, bleomycin treatment of Huh7 with mutant p53 did not result in upregulation of the CD95L (Fig. 5 B). These findings suggested that bleomycin-induced apoptosis in HepG2 cells with wt p53 might be mediated, at least in part, by the activity of the CD95L. The assumption that apoptosis induced by bleomycin in HepG2 cells is mediated via the CD95/ CD95L system was strongly supported by CD95 blocking experiments. Fig. $5 \mathrm{C}$ shows that bleomycin-induced apoptosis after $72 \mathrm{~h}$ of culture can almost completely be inhibited by $\mathrm{F}(\mathrm{ab})^{\prime}{ }_{2}$-anti-APO-1 antibody fragments, known to interfere with CD95 receptor/ligand interaction (37). Thus, bleomycininduced apoptosis is mediated, at least in part, through a death signal by increased expression of CD95L binding to the CD95 receptor. Furthermore, in long-term $\left[{ }^{3} \mathrm{H}\right]$ thymidine-labeled cultures, we could show that treatment with $\mathrm{F}(\mathrm{ab}){ }_{2}{ }_{2}$-anti-APO-1 antibody fragments affects true survival of the cells. Thus, the proliferation of treated HepG2 cells was double to triple that of HepG2 cells treated with bleomycin only. These data show that $\mathrm{F}(\mathrm{ab})^{\prime}{ }_{2}$-anti-APO-1 antibody treatment affects true survival in HepG2 cells treated with cytotoxic drugs and does not simply delay the kinetics of death in the cells.

Anticancer drugs with different mechanisms of action induce apoptosis via the CD95 system. Cisplatin and methotrexate have been shown to trigger nuclear accumulation of the tumor suppressor protein p53 (49). Cisplatin and methotrexate treatment lead to a marked increase in CD95 mRNA and protein expression in wild type p53 expressing HepG2 cells. Upon cisplatin treatment, CD95 expression by FACS $^{\circledR}$ analysis was enhanced up to $50 \%$ positive cells. Methotrexate treatment resulted in CD95 receptor upregulation up to $70 \%$ positive cells. As upon bleomycin treatment neither Huh7 cells (mut 220) 


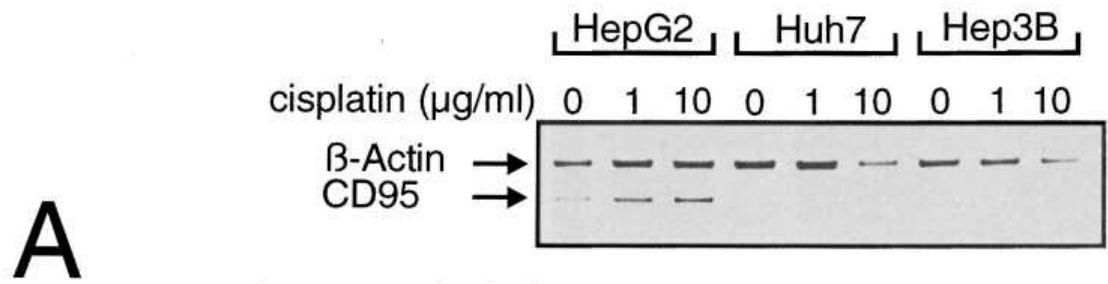

methotrexate $(\mu \mathrm{g} / \mathrm{ml}) 0 \quad 10100 \quad 0 \quad 10100 \quad 0 \quad 10100$

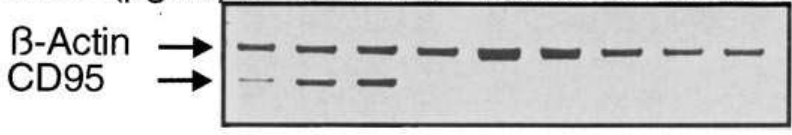

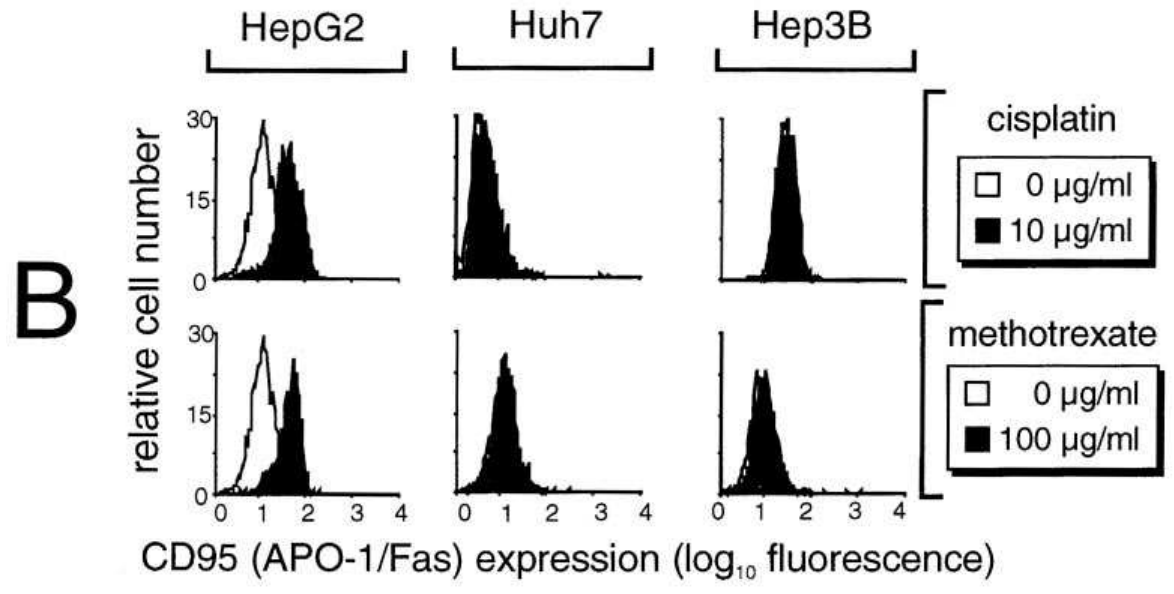

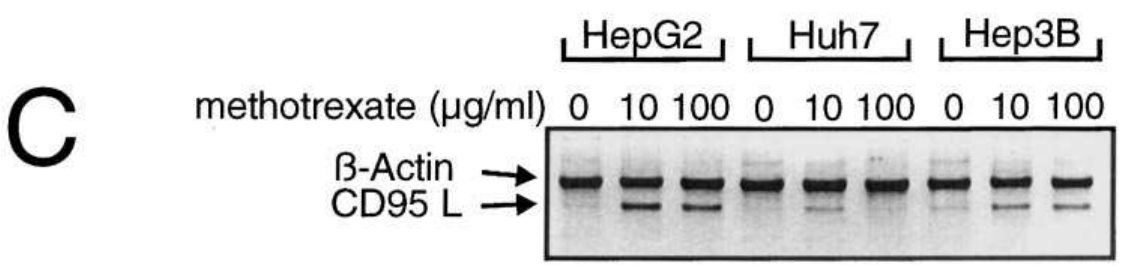

Figure 6. Induction of the CD95 system by anticancer drugs with different mechanisms of action. (A) Semi-quantitative PCR analysis of CD95 receptor mRNA expression in HepG2, Huh7 and Hep3B cells. CD95 mRNA was induced in HepG2 cells (p53 wt) by cisplatin at $1 \mu \mathrm{g} / \mathrm{ml}$ and $10 \mu \mathrm{g} / \mathrm{ml}$ and by methotrexate at $10 \mu \mathrm{g} / \mathrm{ml}$ and $100 \mu \mathrm{g} / \mathrm{ml}$. Huh7 cells with mutant p53 and p53 deficient Hep3B cells did not respond to anticancer therapy with upregulation of CD95 receptor mRNA. (B) CD95 receptor expression by FACS ${ }^{\circledR}$ analysis in HepG2 with wt p53 (left column), Huh7 with mutant p53 (middle column) and Hep3B lacking p53 (right column). Only HepG2 cells displayed enhanced CD95 receptor expression up to $50 \%$ positive cells in response to cisplatin and up to $70 \%$ positive cells in response to methotrexate. $(C)$ CD95 ligand expression after treatment with methotrexate. Semi-quantitative PCR analysis of CD95 ligand mRNA expression in HepG2, Hep3B, and Huh7 cells after treatment with methotrexate at $10 \mu \mathrm{g} / \mathrm{ml}$ and $100 \mu \mathrm{g} / \mathrm{ml}$. Methotrexate induced CD95 ligand mRNA expression in all three cell lines with the exception of the high dose methotrexate in Huh7. The CD95 mRNA expression was weaker in Huh7 cells with mutated p53 than in p53 wt and p53 deficient cells. nor Hep3B cells (p53 -/-) upregulated CD95 mRNA and protein in response to anticancer therapy (Fig. 6, $A$ and $B$ ). This was confirmed by stimulation of CD95 by anti-APO-1 antibodies and concurrent cisplatin or methotrexate treatment. In HepG2 cells treated with cisplatin or methotrexate for $48 \mathrm{~h}$, CD95 receptor stimulation with anti-APO-1 antibodies resulted in further induction of apoptosis in $50 \%$ of the cells compared to cisplatin and methotrexate treatment alone. As in combined bleomycin and anti-APO-1-treatment, anti-APO-1 antibodies did not further enhance apoptosis in comparison with cisplatin and methotrexate alone in Huh7 and in Hep3B cells (data not shown).

Methotrexate treatment induced CD95L mRNA expression at $10 \mu \mathrm{g} / \mathrm{ml}$ and $100 \mu \mathrm{g} / \mathrm{ml}$ in all three cell lines, with the exception of the high dose methotrexate in Huh7 cells. CD95L mRNA expression was weaker in Huh7 cells with mutant p53 than in HepG2 cells (wt p53) and in Hep3B cells (p53-/-) (Fig. 6 C). Cisplatin treatment was not found to initiate CD95L
mRNA expression at $12 \mathrm{~h}, 24 \mathrm{~h}$ and $48 \mathrm{~h}$ after the onset of treatment (data not shown).

Thus, methotrexate- and cisplatin-induced apoptosis involves similar mechanisms as shown for bleomycin treatment.

\section{Discussion}

The data in this paper show that cytotoxicity in hepatoma cells by the anti-cancer drugs bleomycin, doxorubicin, cisplatin, and methotrexate is mediated by induction of apoptosis. In addition, bleomycin treatment resulted in accumulation of nuclear p53 and stimulated increased expression of cell surface CD95 in the drug-sensitive wt p53 hepatocellular carcinoma cell line HepG2. Bleomycin did not increase CD95 in two hepatoma lines with dysfunctional p53. Bleomycin enhanced CD95induced apoptosis in HepG2 cells. In contrast, in p53 mutant Huh7 cells and in p53 negative Hep3B cells, stimulation of 
CD95 does not increase death after bleomycin treatment. Furthermore, bleomycin treatment increased expression of CD95L mRNA. Finally, bleomycin-induced apoptosis in HepG2 cells could almost completely be inhibited by antibodies which block binding of CD95L to the CD95 receptor. Thus, bleomycin-induced apoptosis was shown to be mediated by stimulation of the CD95 receptor/ligand system.

Upregulation of the CD95 system might therefore be a major cause of apoptosis in anticancer therapy. We could show that anticancer drugs with different mechanisms of action, like cisplatin and methotrexate, do also exert their effects via the CD95 (APO-1/Fas) receptor/ligand system. Subsequent to the investigation of CD95 receptor and ligand expression in hepatoma cells, we are currently investigating the involvement of the CD95 receptor/ligand system in the chemotherapeutic treatment of different solid cancers, including gastrointestinal and breast cancer cell lines. Preliminary data indicate that activation of the CD95 system is involved in induction of apoptosis in response to anticancer therapy in different solid human tumor cell lines. Furthermore, data by Friesen et al. (50) show CD95L upregulation in drug induced apoptosis in leukemia cell lines. Apoptosis by the CD95 system might therefore play a general role for cytotoxicity by anti-cancer drugs in a variety of cells of different histotype.

In addition to the data of Friesen et al. (50), which show upregulation of the CD95L in leukemia cell lines, constitutively expressing CD95, we could demonstrate that anticancer agents at concentrations relevant for therapy of patients lead to an upregulation of both, the CD95 receptor and the CD95 ligand in cell lines of a solid human tumor. Thus, upregulation of the CD95 receptor and/or the CD95 ligand might render a tumor cell sensitive towards chemotherapy. On the contrary, drug resistance could result from downregulation of the CD95 receptor. Thus, anticancer agents, stimulating CD95L expression cannot induce apoptosis in tumor cells that have downregulated CD95. This is supported by our findings in Hep3B cells which show stable CD95 receptor expression of only $3 \%$. In these cells CD95 ligand induction by cytotoxic agents does not induce further toxicity. Indeed, in studying the CD95 system in patients with $\mathrm{HCC}$, we could demonstrate loss of CD95 receptor and gain of CD95L expression compared to normal liver tissue (Strand, S., P.H. Krammer and P.R. Galle, manuscript submitted for publication). Alterations of the CD95 receptor/ ligand system might constitute new mechanisms of drug resistance. These mechanisms might exist apart from the known mechanisms of amplification of mdr1, overexpression of bcl-2, BCR-ABL, or mdm2 proteins, or underexpression of DNA topoisomerase II.

Chemoresistance has also been linked to mutations in p53. This is supported by our finding of a reduced responsiveness of Huh7 cells bearing mutant p53 towards bleomycin treatment as compared to the responsiveness of HepG2 cells with wt p53. This demonstrates the requirement of wt p53 for chemotherapy-induced apoptosis in these cells. This requirement has also been shown for a variety of other non-hepatoma cell lines and in animal experiments $(3,51)$. However, there are also conflicting data suggesting that the relation between p53 status and chemoresistance may be tissue-specific (52-54). In fact, mutations of p53 in many human malignancies have been linked to poorer prognosis $(55,56)$.

The action of p53 and its effect on the CD95 receptor/ ligand system is unclear. Our data show that stimulation of the
CD95 receptor did only occur in HepG2 cells with intact p53. Hepatoma cells with mutant p53 and p53 null cell lines did not upregulate the CD95 receptor after cytotoxic therapy. This is supported by our data from the microinjection experiments. Direct injection of wt p53 cDNA into the nucleus of HepG2 cells increased susceptibility towards CD95 mediated apoptosis. These data are in accordance with data by Owen-Schaub et al. (16) demonstrating, that only the wt form of a temperature sensitive mutant of p53 could induce CD95 expression. Stimulation of CD95 expression by p53 was shown to be dependent on transcriptional activity (16). It is possible therefore, that the promoter of the CD95 receptor gene is stimulated by p53 dependent transcriptional activity directly. Alternatively, p53 might activate transcription factors which regulate the CD95 receptor gene. Intact wt p53 is required to mediate such activity. Thus, wt p53 might sense DNA damage in cells treated with anti-cancer drugs such as bleomycin and stimulate expression of the CD95 receptor gene. Our laboratory is currently undertaking experiments to further investigate a possible p53 effect on the CD95 receptor promoter.

Upregulation of the CD95 ligand after bleomycin treatment was demonstrated in p53 wt and p53 deficient hepatoma cell lines, but not in cell lines with mutant p53. This would argue for a gain of function of mutant $\mathrm{p} 53$ in the sense of a possible inhibition of CD95L expression. However, methotrexate treatment resulted in a slight upregulation of the CD95L in Huh7 cells. Thus, the regulation of the CD95L does not solely depend on p53, and p53 independent mechanisms must be involved in the regulation of CD95L.

The function of the CD95 system is complex and involves expression of membrane-bound or soluble CD95 receptor or ligand, a sensitive CD95 receptor signaling pathway and a balance of pro-apoptotic and anti-apoptotic programs (57). Recently, part of the CD95 signaling cascade has been elucidated (reviewed in references 58 and 59). Oligomerization of the CD95 receptor by agonistic anti-CD95 antibodies or by CD95L is essential for the CD95-mediated apoptotic signal. Oligomerization of CD95 causes binding of FADD and the effector protease FLICE, a novel member of the ICE/CED-3 family to the intracellular CD95 associated death-inducing signaling complex (DISC) (60). The assembly of this signaling complex occurs in a hierarchical manner upon receptor activation. The death domain of the receptor binds to the death domain of the adapter molecule FADD, which binds and activates FLICE to generate the most apical enzymatic component of a death cascade composed of other ICE/CED-3 family members (61). Further downstream, after DISC formation, ICE-like proteases $(62,63)$ propagate the apoptotic signal and catalyze a variety of substrates. The CD95 signaling cascade is still incomplete and might be positively or negatively modulated by members of the bcl-2 family $(64,65)$ or the activity of kinases or phosphatases such as RIP, HLP, or FAP-1 (66). Moreover, members of the bcl-2 family have recently been shown to interfere with both the p53 and the CD95 system in some cells. It has been shown that bcl-2 overexpressing mice do not respond to CD95 stimulation with liver failure, in contrast to wt-controls (67). On the other hand, bcl-2 and its antagonist bax have been shown to be regulated by p53 $(68,69)$.

Drug sensitivity or resistance will be affected by alterations of any components of this pathway. Insight into the interactions of the components of the CD95 signaling pathway will therefore provide the basis for modulation of CD95 sensitivity 
and for the development of drugs which either specifically enhance or reduce apoptosis induced by anti-cancer drugs.

It is likely that these data have profound implications for the future management of drug treatment in patients with malignant diseases, particularly for the understanding of drug sensitivity and resistance. Sensitivity to anticancer therapy will therefore depend, at least in part, on the integrity of the p53 and the CD95 receptor/ligand system. In contrast, malfunction of these systems might result in development of drug resistance. This might be useful in a clinical setting to increase cytostatic anti-tumor action and to reduce systemic side effects.

These data may also have implications for p53 gene therapy. In the first phase I clinical trial of p53 gene therapy in lung cancer, Roth and colleagues (70) demonstrated that introduction of wild type p53 into tumor cells resulted in induction of apoptosis of the tumor cells and in control of tumor growth in patients with relapsed lung cancer (whose tumors all carried a p53 mutation). Our data suggest, that upregulation of the CD95 system may account for the apoptosis inducing effect of wild type p53. Thus, wt p53 gene transfer and chemotherapy might cooperate to optimize future cancer therapy.

\section{Acknowledgments}

The expert technical assistance of Martina Seyfert and Young-Gyu Park is gratefully acknowledged. We thank Drs. M. Peter, H. Schaller and K.-M. Debatin for helpful discussion.

This work was supported by grants of the Deutsche Forschungsgemeinschaft (Ga 387/2-3), by the Tumorzentrum Heidelberg/Mannheim and by Forschungsförderung Heidelberg.

\section{References}

1. Fisher, D.E. 1994. Apoptosis in cancer therapy: crossing the threshold. Cell. 78:539-542.

2. Fung, C.Y., and D.E. Fisher. 1995. Shifting the cancer paradigm: must we kill to cure? J. Clin. Oncol. 13:801-807.

3. Lowe, S.W., H.E. Ruley, T. Jacks, and D.E. Housman. 1993. p53-dependent apoptosis modulates the cytotoxicity of anticancer agents. Cell. 74:957-967.

4. Kastan, M.B., O. Onyekwere, D. Sidransky, B. Vogelstein, and R.W. Craig. 1991. Participation of p53 protein in the cellular response to DNA damage. Cancer Res. 51:6304-6311.

5. Kuerbitz, S.J., B.S. Plunkett, W.V. Walsh, and M.B. Kastan. 1992. Wildtype p53 is a cell cycle checkpoint determinant following irradiation. Proc. Natl. Acad. Sci. USA. 89:7491-7495.

6. Kastan, M.B., Q. Zhan, W.S. El-Deiry, F. Carrier, T. Jacks, W.V. Walsh, B.S. Plunkett, and B. Vogelstein. 1992. A mammalian cell cycle checkpoint pathway utilizing p53 and GADD45 is defective in ataxia-teleangiectasia. Cell. 71:587-597.

7. Clarke, A.R., C.A. Purdie, D.J. Harrison, R.G. Morris, C.C. Bird, M.L. Hooper, and A.H. Wyllie. 1993. Thymocyte apoptosis induced by p53-dependent and independent pathways. Nature (Lond.). 362:849-852.

8. Lotem, J., and L. Sachs. 1993. Hematopoietic cells from mice deficient in wild-type p53 are more resistant to induction of apoptosis by some agents. Blood. 82:1092-1096.

9. Lowe, S.W., E.M. Schmitt, S.W. Smith, B.A. Osborne, and T. Jacks. 1993. p53 is required for radiation-induced apoptosis in mouse thymocytes. Nature (Lond.). 362:847-849.

10. Bates, S., and K.H. Vousden. 1996. p53 in signaling checkpoint arrest or apoptosis. Curr. Opin. Genet. Dev. 6:12-19.

11. Harris, C.C. 1996. p53 tumor suppressor gene: from the basic research laboratory to the clinic - an abridged historical perspective. Carcinogenesis. 17: 1187-1198.

12. Barak, Y., T. Juven, R. Haffner, and M. Oren. 1993. Mdm2 expression is induced by wild type p53 activity. EMBO (Eur. Mol. Biol. Organ.) J. 12:461-468.

13. Chen, C.Y., J.D. Oliner, Q. Zhan, A.J. Fornace, Jr., B. Vogelstein, and M.B. Kastan. 1994. Interactions between p53 and MDM2 in a mammalian cell cycle checkpoint pathway. Proc. Natl. Acad. Sci. USA. 91:2684-2688.

14. El-Deiry, W.S., T. Tokino, V.E. Velculescu, D.B. Levy, R. Parsons, J.M. Trent, D. Lin, W.E. Mercer, K.W. Kinzler, and B. Vogelstein. 1993. WAF1, a potential mediator of p53 tumor suppression. Cell. 75:817-825.
15. Smith, M.L., I.T. Chen, Q. Zhan, I. Bae, C.Y. Chen, T.M. Gilmer, M.B. Kastan, P.M. O'Connor, and A.J. Fornace, Jr. 1994. Interaction of the p53-regulated protein Gadd45 with proliferating cell nuclear antigen. Science (Wash. DC). 266:1376-1380.

16. Owen-Schaub, L.B., W. Zhang, J.C. Cusack, L.S. Angelo, S.M. Santee, T. Fujiwara, J.A. Roth, A.B. Deisseroth, W.W. Zhang, E. Kruzel, and R. Radinsky. 1995. Wild-type human p53 and a temperature-sensitive mutant induce FAS/APO-1 expression. Mol. Cell Biol. 15:3032-3040.

17. Trauth, B.C., C. Klas, A.J.M. Peters, S. Matzku, P. Möller, W. Falk, K.M. Debatin, and P.H. Krammer. 1989. Monoclonal antibody-mediated tumor regression by induction of apoptosis. Science (Wash. DC). 245:301-305.

18. Inazawa, J., H. Itoh, T. Abe, and S. Nagata. 1992. Assignment of the human Fas antigen gene (FAS) to 10q24.1. Genomics. 14:821-822.

19. Itoh, N., S. Yonehara, A. Ishii, M. Yonehara, S.I. Mizuchima, M. Sameshima, A. Hase, Y. Seto, and S. Nagata. 1991. The polypeptide encoded by the cDNA for human cell surface antigen Fas can mediate apoptosis. Cell. 66: 233-243.

20. Smith, C.A., T. Farrah, and R.G. Goodwin. 1994. The TNF receptor superfamily of cellular and viral proteins: activation, costimulation and death. Cell. 76:959-962.

21. Suda, T., T. Takahashi, P. Goldstein, and S. Nagata. 1993. Molecular cloning and expression of the Fas ligand, a member of the tumor necrosis factor family. Cell. 75:1169-1178.

22. Berke, G. 1995. The CTL's kiss of death. Cell. 81:9-12.

23. Lowin, B., M. Hahne, C. Mattmann, and J. Tschopp. 1994. Cytolytic T-cell cytotoxicity is mediated through perforin and Fas lytic pathways. Nature (Lond.). 370:650-652.

24. Kägi, D., F. Vignaux, B. Ledermann, K. Bürki, V. Depraetere, S. Nagata, H. Hengartner, and P. Golstein. 1994. Fas and perforin pathways as major mechanisms of T-cell-mediated cytotoxicity. Science (Wash. DC). 265:528-530.

25. Galle, P.R., W.J. Hofmann, H. Walczak, H. Schaller, G. Otto, W. Stremmel, P.H. Krammer, and L. Runkel. 1995. Involvement of the APO-1/Fas (CD95) receptor and ligand in liver damage. J. Exp. Med. 182:1223-1230.

26. Ogasawara, J., R. Watanabe Fukunaga, M. Adachi, A. Matsuzawa, T. Kasugai, Y. Kitamura, N. Itoh, T. Suda, and S. Nagata. 1993. Lethal effect of the anti-Fas antibody in mice. Nature (Lond.). 364:806-809.

27. Owen-Schaub, L.B., R. Radinsky, E. Kruzel, K. Berry, and S. Yonehara. 1994. Anti-Fas on nonhematopoietic tumors: levels of Fas/APO-1 and bcl-2 are not predictive of biological responsiveness. Cancer Res. 54:1580-1586.

28. Aden, D.P., A. Fogel, S. Plotkin, I. Damjanov, and B.B. Knowles. 1979. Controlled synthesis of HBsAg in a differentiated human liver carcinomaderived cell line. Nature (Lond.). 282:615-616.

29. Nakabayashi, H., K. Taketa, T. Yamane, M. Miyazaki, K. Miyano, and J. Sato. 1984. Phenotypical stability of a human hepatoma cell line, HuH-7, in long-term culture with chemically defined medium. Jpn. J. Cancer Res. 75:151-158.

30. Hsu, I.C., T. Tokiwa, W. Bennett, R.A. Metcalf, J.A. Welsh, T. Sun, and C.C. Harris. 1993. p53 gene mutation and integrated hepatitis B viral DNA sequences in human liver cancer cell lines. Carcinogenesis. 14:987-992.

31. Ponchel, F., A. Puisieux, E. Tabone, J.P. Michot, G. Froschl, A.P. Morel, T. Frebourg, B. Fontaniere, F. Oberhammer, and M. Ozturk. 1994. Hepatocarcinoma-specific mutant p53-249ser induces mitotic activity but has no effect on transforming growth factor beta 1-mediated apoptosis. Cancer Res. 54:20642068.

32. Hall, S.W., J.E. Strong, A. Broughton, M.L. Frazier, and R.S. Benjamin. 1982. Bleomycin clinical pharmacology by radioimmunoassay. Cancer Chemother. Pharmacol. 9:22-25.

33. Shea, T.C., M. Flaherty, A. Elias, J.P. Eder, K. Antman, C. Begg, L. Schnipper, E. Frei III, and W. D. Henner. 1989. A phase I clinical and pharmacokinetic study of carboplatin and autologous bone marrow support. J. Clin. Oncol. 7:651-661.

34. Kurihara, N., T. Kubota, Y. Hoshiya, Y. Otani, N. Ando, K. Kumai, and M. Kitajima. 1996. Pharmacokinetics of cis-diamminedichloroplatinum (II) given as low-dose and high-dose infusions. J. Surg. Oncol. 62:135-138.

35. Evans, W.E., W.R. Crom, M. Abromowitch, R. Dodge, A.T. Look, W.P. Bowman, S.L. George, and C. Pui. 1986. Clinical pharmacodynamics of highdose methotrexate in acute lymphocytic leukemia. N. Engl. J. Med. 314:471-477.

36. Muller, C., E. Chatelut, V. Gualano, M. De Forni, F. Huguet, M. Attal, P. Canal, and G. Laurent. 1993. Cellular pharmacokinetics of doxorubicin in patients with chronic lymphocytic leukemia: Comparison of bolus administration and continuous infusion. Cancer Chemother. Pharmacol. 32:379-384.

37. Dhein, J., P.T. Daniel, B.C. Trauth, A. Oehm, P. Möller, and P.H. Krammer. 1992. Induction of apoptosis by monoconal antibody anti-APO-1 class switch variants is dependent on cross-linking of APO-1 cell surface antigens. J. Immunol. 149:3166-3173.

38. Dhein, J., H. Walczak, C. Bäumler, K.M. Debatin, and P.H. Krammer. 1995. Autocrine T-cell suicide mediated by APO-1/(Fas/CD95). Nature (Lond.). 373:438-441.

39. Steel, G.G., and M.J. Peckham. 1979. Exploitable mechanisms in combined radiotherapy-chemotherapy: the concept of additivity. Radiation Oncology Biol. Phys. 5:85-91.

40. Chou, T.C., and P. Talalay. 1984. Quantitative analysis of dose-effect relationships: the combined effects of multiple drugs or enzyme inhibitors. $A d v$. 
Enzyme Regul. 22:27-55

41. Volkmann, M., W.J. Hofmann, M. Müller, U. Räth, G. Otto, H. Zentgraf, and P.R. Galle. 1994. p53 overexpression is frequent in European hepatocellular carcinoma and largely independent of the codon 249 hot spot mutation. Oncogene. 9:195-204.

42. Volkmann, M., M. Müller, W.J. Hofmann, M. Meyer, J. Hagelstein, U. Räth, B. Kommerell, H. Zentgraf, and P.R. Galle. 1993. The humoral immune response to p53 in patients with hepatocellular carcinoma is specific for malignancy and independent of the alpha-fetoprotein status. Hepatology. 18:559-565.

43. Nicoletti, I., G. Migliorati, M.C. Paggliacci, F. Grignani, and C. Riccardi. 1991. A rapid and simple method for measuring thymocyte apoptosis by propidium iodide staining and flow cytometry. J. Immuno. Methods. 139:271-279.

44. Sellins, K.S., and J.J. Cohen. 1987. Gene induction by gamma-irradiation leads to DNA fragmentation in lymphocytes. Immunology. 139:3199-3206.

45. Gavrieli, Y., Y. Sherman, and S.A. Ben Sasson. 1992. Identification of programmed cell death in situ via specific labeling of nuclear DNA fragmentation. J. Cell Biol. 119:493-501.

46. Angerer, L.M., and R.C. Angerer. 1992. In situ hybridization to cellular RNA with radiolabeled RNA probes. In In situ hybridization. A practical approach. D.G. Wilkinson, editor. Oxford University Press Inc., New York. 15-32.

47. Peter, M.E., J. Dhein, A. Ehret, S. Hellbardt, H. Walczak, G. Moldenhauer, and P.H. Krammer. 1995. APO-1(CD95)-dependent and -independent antigen receptor-induced apoptosis in human $\mathrm{T}$ and $\mathrm{B}$ cell lines. Int. Immunol. 7:1873-1877.

48. Wong, G.H.W., and D. Goeddel. 1994. Fas antigen and p55 TNF receptor signal apoptosis through distinct pathways. J. Immunol. 152:1751-1755.

49. Fritsche, M., C. Haessler, and G. Brandner. 1993. Induction of nuclear accumulation of the tumor-suppressor protein p53 by DNA-damaging agents [published erratum appears in Oncogene 1993 Sep;8(9):2605]. Oncogene. 8: 307-318.

50. Friesen, C., I. Herr, P.H. Krammer, and K.M. Debatin. 1996. Involvement of the CD95 (APO-1/Fas) receptor/ligand system in drug-induced apoptosis in leukemia cells. Nat. Med. 2:574-580.

51. Wu, S.G., and W.S. El-Deiry. 1996. p53 and chemosensitivity. Nat. Med. 2:255-256

52. Delia, D., S. Mizutani, G. Lamorte, K. Goi, S. Iwata, and M.A. Pierotti. 1996. p53 activity and chemotherapy. Nat. Med. 2:724-725.

53. Hawkins, D.S., G.W. Demers, and D.A. Galloway. 1996. Inactivation of p53 enhances sensitivity to multiple chemotherapeutic agents. Cancer Res. 56: 892-898.

54. Wahl, A.F., K.L. Donaldson, C. Fairchild, F.Y. Lee, S.A. Foster, G.W. Demers, and D.A. Galloway. 1996. Loss of normal p53 function confers sensitization to Taxol by increasing G2/M arrest and apoptosis. Nat. Med. 2:72-79.

55. Bardeesy, N., D. Falkoff, M.J. Petruzzi, N. Nowak, B. Zabel, M. Adam, M.C. Aguiar, P. Grundy, T. Shows, and J. Pelletier. 1994. Anaplastic Wilms' tumour, a subtype displaying poor prognosis, harbours p53 gene mutations. Nat. Genet. 7:91-97.

56. Wada, M., C.R. Bartram, H. Nakamura, M. Hachiya, D.L. Chen, J. Borenstein, C.W. Miller, L. Ludwig, T.E. Hansen Hagge, and W.D. Ludwig. 1993.
Analysis of p53 mutations in a large series of lymphoid hematologic malignancies of childhood. Blood. 82:3163-3169.

57. Krammer, P.H., I. Behrmann, P. Daniel, J. Dhein, and K.M. Debatin. 1994. Regulation of apoptosis in the immune system. Curr. Opin. Immunol. 6 279-289.

58. Peter, M.E., F.C. Kischkel, S. Hellbardt, A.M. Chinnaiyan, P.H. Krammer, and V.M. Dixit. 1996. CD95 (APO-1/Fas)-associating signaling proteins. Cell Death Differ. 3:161-170.

59. Fraser, A., and G. Evan. 1996. A license to kill. Cell. 85:781-784.

60. Kischkel, F.C., S. Hellbardt, I. Behrmann, M. Germer, M. Pawlita, P.H. Krammer, and M.E. Peter. 1995. Cytotoxicity-dependent APO-1 (Fas/CD95) associated proteins form a death-inducing signaling complex (DISC) with the receptor. EMBO (Eur. Mol. Biol. Organ.) J. 14:5579-5588.

61. Muzio, M., A.M. Chinnaiyan, F.C. Kischkel, K. O'Rourke, A. Shevchenko, J. Ni, C Scaffidi, J.D. Bretz, M. Zhang, R. Gentz, M. Mann, P.H. Krammer, M.E. Peter, and V.M. Dixit. 1996. FLICE, a novel FADD-homologous ICE/CED-3-like protease, is recruited to the CD95 (Fas/APO-1) deathinducing signaling complex. Cell. 85:817-827.

62. Enari, M., H. Hug, and S. Nagata. 1995. Involvement of an ICE-like protease in Fas-mediated apoptosis. Nature (Lond.). 375:78-81.

63. Los, M., M. Van de Craen, L.C. Penning, H. Schenk, M. Westendorp, P.A. Baeuerle, W. Dröge, P.H. Krammer, W. Fiers, and K. Schulze-Osthoff. 1995. Requirement of an ICE/CED-3 protease for Fas/APO-1-mediated apoptosis. Nature (Lond.). 375:81-83.

64. Jaattela, M., M. Benedict, M. Tewari, J.A. Shayman, and V.M. Dixit. 1995. Bcl-x and Bcl-2 inhibit TNF and Fas-induced apoptosis and activation of phospholipase A2 in breast carcinoma cells. Oncogene. 10:2297-2305.

65. Strasser, A., A.W. Harris, P.H. Krammer, and S. Cory. 1995. Bcl-2 and Fas/APO-1 regulate distinct pathways to lymphocyte apoptosis. EMBO (Eur. Mol. Biol. Organ.) J. 14:6138-6147.

66. Menon, S.D., G.R. Guy, and Y.H. Tan. 1995. Involvement of a putative protein-tyrosine phosphatase and I kappa B-alpha serine phosphorylation in nuclear factor kappa B activation by tumor necrosis factor. J. Biol. Chem. 270 18881-18887.

67. Lacronique, V., A. Mignon, M. Fabre, B. Viollet, N. Rouquet, T. Molina, A. Porteu, A. Henrion, D. Bouscary, P. Varlet, V. Joulin, and A. Kahn. 1996. Bcl-2 protects from lethal hepatic apoptosis induced by an anti-Fas antibody in mice. Nat. Med. 2:80-86.

68. Miyashita, T., S. Krajewski, M. Krajewska, H.G. Wang, H.K. Lin, D.A Liebermann, B. Hoffman, and J.C. Reed. 1994. Tumor suppressor p53 is a regulator of bcl-2 and bax gene expression in vitro and in vivo. Oncogene. 9:17991805 .

69. Miyashita, T., and J.C. Reed. 1995. Tumor suppressor p53 is a direct transcriptional activator of the human bax gene. Cell. 80:293-299.

70. Roth, J.A., D. Nguyen, D.D. Lawrence, B.L. Kemp, C.H. Carrasco, D.Z. Ferson, W.K. Hong, R. Komaki, J.C. Lee, J.J. Nesbitt, et al. 1996. Retrovirus-mediated wild-type p53 gene transfer to tumors of patients with lung cancer. Nat. Med. 2:985-991. 